\title{
Å bære en fakkel
}

\author{
Jeg har lært at man i politikken \\ alltid skal snakke om elefanten \\ i rommet - det de som leser tenker \\ på om du ikke sier noe. Det som \\ forstyrrer bildet. Elefanten i rom- \\ met kan være at jeg er sårbar \\ for bipolar lidelse. Og at jeg sitter \\ på Stortinget. Det er nå rundt \\ halvannet år siden jeg fortalte \\ offentlig om dette gjennom en \\ kronikk i Aftenposten. Det var en \\ gjennomtenkt handling. Formålet \\ var å fjerne fordommer. Det har \\ vært en positiv opplevelse.
}

Det er et privilegium å ha muligheten til å bruke en offentlig arena til å fortelle om symptomer og sykdom for å opplyse og spre kunnskap. Jeg tenkte at ikke alle hadde den muligheten.

Tilbakemeldingene har kommet fra folk flest, og de har vært veldig varme og fine. Når jeg beveger meg i det offentlige rom, blir jeg garantert trukket til side for å snakke om psykisk helse. Det er mennesker som har sett eller opplevd. Det føles nærere og varmere enn å snakke om det nyeste innen tallerkener eller en vei som bør bygges. Det føles som å gå i dybden av det menneskelige liv.

Men det at samtalene bare foregår under fire øyne, forteller meg at området er svært tabubelagt. Og spørsmålene jeg får er så mange. Tankene går tilbake til boken Fra de stummes leir av Camilla Collett om kvinners stilling, og Den lukkede bok av Jette Kaarsbøl som tar for seg seksuell legning i en tid hvor det var tabu.

En del av historiene jeg får høre, er svært tankevekkende. Det handler om ikke å ha mot til å si til foreldrene at man sliter alvorlig eller om å leve i bekymring for sin ektefelle. Noen vil ikke si noe til barna sine, fordi de er opptatt av at alt skal være normalt. Noen forteller at de heller sier de går til tannlegen enn å fortelle sjefen om diagnosen sin. Andre beskriver et møte med et helsevesen som ikke forstår, som tar fra dem håp. Tar du håpet fra et menneske, tar du livsmotet også. En del føler det ikke snakkes om den lange veien tilbake fra sykdom.

Noen ønsker bare å snakke med en som er syk, og som lever godt med sårbarhet for sykdom. Det å lytte til historier, og snakke om politikk går greit for meg. Bortsett fra at jeg får lyst til å rette opp alt som er feil da. Men det kan være en utfordring generelt sett for andre og meg å leve åpent med en diagnose.

Jeg har bekymringer en del andre mennesker slipper. Når man har en diagnose, er man også redd for at andre skal se en gjennom «diagnosebrillene». At de skal tenke: «Det gjør hun jo bare fordi hun er litt ja, sånn annerledes», selv om mine handlinger er innenfor normalitetens definisjoner, hva nå det er. Man blir litt var for om noen tror man er sin egen lidelse.

Og så, i den grad jeg er annerledes, har jeg lurt på om det er rom for meg i samfunnet. For det er slik at jeg lever med noder som danser sin dans. I perioder har jeg så stor styringsfart at mennesker er litt i veien for fremdriften. Har tusen ideer, skriver, og får gjort veldig mye bra også, og noe sprøtt. I tillegg er det dette med svekket impulskontroll. Og så trenger jeg ro. Trekker meg tilbake. Vil sove. Blir litt fjern rett og slett. Sliten.

Så er jeg jo meg imellom. Og det blir vanskelig for folk å skille. Jeg er redd for hva de tenker om meg når jeg har vært i flytsonen. Hvordan de reagerer. Jeg er redd for den kalde utstøtelsen. Den som er like smertefull som fysisk smerte. Og så er det dette med å bli begrenset av sykdom. Vi skal ikke bli utsatt for så mye stress, men jeg synes at jeg selv kan bestemme hvor mye stress jeg tåler.

Det er mye å bekymre seg for. Som sårbar for sykdom er det kanskje slik at jeg må forklare. At det blir litt mitt ansvar. Tilbakemeldingene jeg får er at bekymringene jeg har er ubegrunnet. At folk ikke tenker på det, og det får jeg tro på.

Jeg har tilgang til arenaer der jeg kan ta opp viktige politiske spørsmål, og bli lyttet til. Mitt politiske $\varnothing n s k e$ har vært å være med på å gi et bidrag til å se psykisk helse i et folkehelseperspektiv. Det angår alle på en eller annen måte, fordi alle har en psykisk helse. Deretter har jeg vært opptatt av at folk skal få hjelp når de trenger det, og at de som må leve med psykisk sykdom skal ha et verdig liv.

Det har vært riktig å være åpen om sårbarheten for sykdommen. Det gir legitimitet på den politiske arena for et viktig samfunnsområde. Fordelen er at det også har blitt lettere å være meg og leve med dette. Fordi folk forstår mer. Og bare kunnskap fjerner fordommer. Det har blitt lettere å bære en fakkel for oss sårbare for sykdom.

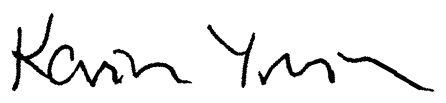

